\title{
Socio-Educational Factors to Promote Educational Inclusion in Higher Education. A Question of Student Achievement
}

\author{
Mª del Mar García-Vita ${ }^{1}$, Marta Medina-García ${ }^{2}$, Giselle Paola Polo Amashta ${ }^{3}$ and Lina Higueras-Rodríguez ${ }^{1, *(D)}$ \\ 1 Department of Education, University of Almería, 04120 Almería, Spain; margvita@ual.es \\ 2 Department of Pedagogy, University of Jaén, 23071 Jaén, Spain; mameding@ujaen.es \\ 3 Institute of Education Studies, University of North, Barranquilla 080020, Colombia; \\ gamashta@uninorte.edu.co \\ * Correspondence: mlinahr@ual.es
}

check for updates

Citation: García-Vita, M.d.M.;

Medina-García, M.; Polo Amashta, G.P.; Higueras-Rodríguez, L. Socio-Educational Factors to Promote Educational Inclusion in Higher Education. A Question of Student Achievement. Educ. Sci. 2021, 11, 123. https://doi.org/10.3390/educsci 11030123

Received: 7 February 2021

Accepted: 11 March 2021

Published: 13 March 2021

Publisher's Note: MDPI stays neutral with regard to jurisdictional claims in published maps and institutional affiliations.

Copyright: (C) 2021 by the authors. Licensee MDPI, Basel, Switzerland. This article is an open access article distributed under the terms and conditions of the Creative Commons Attribution (CC BY) license (https:// creativecommons.org/licenses/by/ $4.0 /)$.

\begin{abstract}
Psychosocial factors have a direct impact on the academic achievement of university students, especially when they belong to diverse human groups. This article shows the results of a project developed in a Colombian university with the aim of finding out the identity traits, situations of discrimination, and risk factors faced by students belonging to diverse groups. The research is qualitative, exploratory, and descriptive, approached from a social and educational perspective. Semi-structured interviews were conducted with 15 students. The high level of identification with the group is visible in stufuigureents with affective-sexual diversity, gender identity and ethnic-cultural diversity, considered to be the most discriminated-against populations. Risks in the labor, educational, social, and family spheres are the most frequent.
\end{abstract}

Keywords: higher education; human diversity; identity; discrimination; risk factors; student achievement

\section{Introduction}

This work is part of the research project Human Diversity and Inclusive Higher Education in a university in Colombia. This work explores the human diversity existing among the student body of the university institution in terms of identity traits, establishing as lines of future work the projection of a line of action aimed at the development of Inclusive Higher Education, currently promoted by the National Ministry of Education of Colombia (MEN).

Education as an eminently socializing process enables interaction between subjects, characterized by differences that constitute human diversity; therefore, education systems, and within them higher education levels, should not fail to develop proposals that address this diversity in training scenarios [1,2]. The exercise of the right to education based on the principles of non-discrimination and full participation [3], to which university educational institutions also adhere, means that the educational system as a whole must respond to the needs of the diverse populations they serve, as well as protect and promote their rights in accordance with the current regulatory guidelines, both in the Colombian context, on which this work is based [4], and in accordance with international bodies [5-8]. Our proposal is developed in a university context that has seen how the profile of its student population has diversified in recent years, increasing the diversity present in the classrooms and in the institution.

To refer to inclusive education, we must start from a key idea. It is not a pedagogical trend but a legal imperative sufficiently supported at the legal and regulatory level [9]. It is compulsory for the entire education system, including the university stage [10]. As Porter and Stone [11] point out, the paradigm of educational inclusion is characterized by guaranteeing equity for all students. Therefore, the construction of inclusive educational environments implies a change in educational policies, school culture and teaching 
methodology $[12,13]$. An educational institution that is committed to inclusion must offer opportunities for all students to achieve school and social success according to the socio-personal peculiarities of each student $[14,15]$.

In Colombia, aware of this, education policies seek to close the existing gaps in the face of segregation and discrimination, prioritizing policies and actions related to educational inclusion and inclusive education at all levels of education. There is public recognition of social and educational inequalities and difficulties based on differences in gender and sexuality, socio-economic origin and belonging, and ethnicity/race and disability; although efforts have been made to understand the differences in academic performance associated with this situation, there are still few studies on this subject. There are many research studies and proposals for action that address the issue of equity in higher education, identifying the needs for attention to diversity and thus avoiding the reproduction of power structures and limited opportunities throughout university education [16]. We must be clear that Inclusive Education is not synonymous with Social Inclusion, but it is one of its possible impacts. The higher education institutions must be aware of the types of social injustice that can be generated within them by the fact of working with diverse communities [17] and generate actions aimed at alleviating and eliminating them. The materialization of strategies for Inclusive Higher Education is linked to the construction of proposals that comply, according to the United Nations Educational, Scientific and Cultural Organization (UNESCO) [6], with the recognition of inclusion as a process in which better ways of respecting diversity must be constantly sought and greater attention must be given to the most vulnerable population groups or those at risk of exclusion.

To know directly from the voice of the protagonists of the educational processes, that is, the students, what are their feelings of belonging to certain human groups-in their levels of ascription and identification - as well as the situations of discrimination and risk factors that they have suffered or consider that they are exposed to as part of the collective [18-20], becomes key to be able to set objectives of a propositional and action type in the university institution, as well as a priority for the construction of participatory spaces and truly inclusive educational environments. That is why, in this research, we propose to find out how higher education students conceive diversity and how they perceive themselves; what types of prejudice and discrimination are recognized by different groups of students; what are the psychosocial risk factors found in the student population in higher education; and what is their impact on educational practice.

\section{Inclusion at University: Academic and Psychosocial Achievement}

The pursuit of academic achievement and student success begins to form part of a properly inclusive and quality educational model [15]. In this sense, many supporters of inclusive education consider that this perspective achieves benefits both in terms of social justice and academic effectiveness. Some research concludes that students with disabilities achieve higher academic and social gains in inclusive contexts than in segregated contexts [21,22]. Similarly, Sánchez-Teruel and Robles-Bello [23] indicate that inclusive education practices lead to improvements in interpersonal relationships and academic achievement. Significantly, the results of the work of Angenscheidt \& Navarrete [12] show that $68 \%$ of the respondents in the paper affirm that inclusion has more positive than negative aspects. Therefore, we can say that achievement is considered a key indicator of inclusion assurance [21].

Specifically, in the university environment, achieving inclusion is a challenge that must be faced urgently. The success of this paradigm in secondary education implies for the university institution the need to implement actions and strategies that lead to the adequate implementation of inclusion at this educational stage $[2,24,25]$. The university will need many elements and transformations to achieve the inclusion of its students [25]. Research by Gale and Hodge [26] points to more theoretical knowledge and more practical action on social inclusion. Inclusion at university is not only measured in terms of academic achievement, but as social inclusion is also emerging as a factor of quality and success [27]. 
Inclusion in higher education is generally perceived positively. However, certain aspects need to be improved to provide truly inclusive university environments [28]. One of these issues is reflected in the low number of students with disabilities in higher education, which stands at $1.5 \%$ of the total, according to the latest data published in the "Guide to disability care" (2018) [9]. In other contexts, the under-representation of students from disadvantaged or minority ethnic backgrounds has also been highlighted [29-31]. In the disability domain, these deficits present themselves as problematic aspects of the teaching process, assessment, and access to and use of information [32]. The findings of Moriña and Perera [33] point out as barriers to the achievement of university inclusion aspects such as: organizational and architectural support, teacher training and the need to build accessible learning environments. Further the work of Martins, Borges and Gonçalves [28] shows the general shortcomings in the real development of the social model of disability.

In the framework of inclusive education, one of the dilemmas is whether to produce differences in students' development in view of the diversity present. The findings of the study by Ruijs, Van der Veen, and Peetsma [29] indicate that there are hardly any differences in academic and socio-emotional aspects. However, the way in which the education system is organized has a clear impact on the psychosocial development of students, as in the case of the inclusive rural school in Aysanoa's study [30]. In this sense, to know the effectiveness of an education system such as an inclusive one, academic and psychosocial achievement must be assessed [31-35]. This relationship has traditionally been understood to occur [36,37] and is now reaffirmed by research such as Walker and Nabuzoka [38], Malecki and Elliott [39], Wentzel [40], and Szumski and Karwowski [41], which point to the correlation between psychosocial aspects and educational achievement.

Social, emotional, and psychological factors are key to achieving a true and complete inclusive and social education, as reflected in the work of Valero and Viñas [42] on the educational and social inclusion of immigrant students. Deficits in the implementation of educational inclusion affect psychosocial elements that have an impact on student wellbeing, as stated by Mora et al. [43]. In short, the findings of the research by Álvarez and Cázarez [44] conclude that psychosocial aspects are fundamental issues for educational inclusion, and their relationship is reaffirmed in more and more studies, as pointed out by Vélez et al. [45].

\section{Identity and Human Diversity}

Personal and collective identity, understood as a continuous and dynamic sociocultural construction, reconstruction, and co-construction [46,47], is the result of relational processes with others and is explained from the perspective of ecological development proposed by Bronfenbrenner [48], and social and cultural interactions in macro and micro contexts $[18,49,50]$. In this paper, we inquire about students' sense of personal identity and their belonging to groups of human diversity. The participating students were selected by assessing their traits or characteristics in their life trajectories, which suggest the possibility that they feel part of different population samples of human diversity. However, since collective identity is not an imposition but a choice on the part of individuals, belongingascription and identification and awareness with the group [18-20] to such groups does not always occur. In fact, in the presentation of the results, we will see that this is the case.

This participant selection design was proposed because it is the approach that the Colombian Ministry of National Education has been working on since 2007 when talking about diversity and inclusion, considering the differential population approach by examining groups such as people with disabilities, ethnic groups or victims of the conflict and border areas [4]. These population-based emphases were expanded in our study in accordance with theoretical orientations and international recommendations, including students whose socio-economic origin implies a differentiation and those affected by inequalities based on gender and sexuality [16].

Diversity alludes to the circumstance of subjects being distinct and different, although it also refers, on the other hand, to the fact that difference is not always neutral and gener- 
ates social and educational inequality [51-53], which occurs when the characteristics of human diversity are collective or the result of the context in which they are located [15,54-56], recognizing plurality from a particular place based on cultural hegemony [57-59]. Despite the vicissitudes that the concept of diversity awakens - and the voices that prefer to use the term difference-we advocate continuing to make use of it, understanding it from the encounter between subjects and between collectives, rethinking the feelings of belonging and those that we generate in the face of otherness, being a matter of all of us making an active recognition of it. As Morin [60] says, education must study human complexity, which leads us to:

The awareness of the common condition of all humans, and of the extraordinarily rich and necessary diversity of individuals, peoples, cultures, of our rootedness as citizens of the Earth (...). (p.31).

As Escudero and Martínez [61] put it: “( . . ) inclusive education belongs to the universe of ethics, social justice, deep democracy and equity ( . . . )" (p.88). Thus, the aim of any higher education institution that intends to be traversed by the Inclusive Education approach must be to offer opportunities for knowledge and human development. Inclusive education begins by getting to know students and other members of the educational community, as a never-ending search for better ways to respond to diversity $[1,17,62]$. In this process of approaching the student community, it is necessary to recognize difficulties, risk factors, needs, prejudices, and different forms of discrimination.

\section{The Concept of Discrimination and Typology}

Recognizing the significance of human diversity and learning to live with differences is a difficult task that requires primarily the reduction of prejudice and discriminatory behavior towards diversity [63].

At a conceptual level, a prejudice is considered as a negative activity that is exercised towards a person who is a member of a social group or specifically towards the group in general. These have three components: cognitive, associated with beliefs; affective, associated with emotions; and behavioral, i.e., behaviors [64-66]. Regarding discrimination, Brander et al. [67] also agree with Montes [64] in defining it as unequal, unfavorable, and different treatment towards a group or subject, which is a consequence of prejudice. Both argue that discrimination is the result of prejudices that are constructed by people, with prejudices being determinant for discrimination, i.e., they could be considered as the basis and justification that directly generates discrimination, which is evidenced in concrete acts. In prejudice, the cognitive and affective, abstract, and non-tangible components are more relevant. When these components are translated and materialized in actions, behaviors and/or acts, this is what is conceptualized as discrimination, what is evident and tangible. Discrimination is generally based on age, disability, sex or gender, sexual orientation, beliefs, ethnicity, origin, race, language, culture, and religion, among others; the contexts and root causes of marginalization, discrimination, and exclusion are very varied [68].

It should be noted that discrimination can be classified according to the type of act developed, that is, according to the way in which it manifests itself. In this sense, the following classification has been suggested in the literature: direct discrimination, indirect discrimination, structural discrimination, and multiple or intersectional discrimination [67,69-75]. Direct discrimination is attributed to an intention to carry out a discriminatory action, conduct and/or act towards a person or a group, and is characterized by being deliberate, clear, evident, and explicit. It is a situation in which an individual or a group is treated differently, less favorably, and prejudicially, because of some factor that differentiates them from the ordinary. Indirect discrimination is considered in some cases to be unconscious acts and not presented in a clear, explicit, or overt manner. It occurs when a practice, criterion, rule, or provision creates a disproportionate disadvantage or has a detrimental impact on members of a social group. Structural discrimination is a type of inequality that is based on status, decision making, and power identities, and is rooted in the way society is organized, in institutional, legal, organizational, and other structures. Finally, 
multiple, or intersectional discrimination is defined as that which occurs when a person is discriminated against for different reasons at the same time or at different times, i.e., when there is an accumulation of many experiences of discrimination.

\section{Educational and Social Risk Factors in Diverse Population Groups}

The term risk factor has been used by studies of various kinds and from different disciplines to explain those elements or variables that converge and negatively influence aspects of a subject's life. A risk factor, according to Hein [76], refers to the presence of contextual or personal situations that, when present, increase the probability of developing social, emotional, behavioral, or health problems. The presence of a risk factor or risk factors is a probabilistic and non-deterministic concept. Risk cannot be equated with cause; they are predictors but not necessarily a single, direct cause and, in addition, they are different variables that interact and should be considered as dynamic and not in isolation. As Tisseron [77] points out, the notion of risk factors helps to understand personal and social difficulties, but the presence of numerous risk factors in the same personal situation, without any other type of assessment, could lead one to think that change is impossible, i.e., to deny the possibility of improving the personal situation. This scheme has been replaced by approaches with a socializing and re-educational basis that take into consideration the need to balance risk factors with the potential of the subject and the environment in which he/she develops (risk factors, resilience, etc.). However, we should not ignore the fact that the risk approach remains a priority in a process of studying vulnerable populations, at least in the diagnostic phase.

Risk factors can be environmental/contextual, individual, psychological and, finally, risk factors based on socializing criteria where family, peer group relationships, and those related to the school or educational context (when we are talking about childhood, adolescence, and youth) come into play. Age, gender, and origin and/or ethnicity are the axes of social inequality that crosses any situation of exclusion [78-82].

In this paper, we consider factors that pose a risk for people who belong to diverse or traditionally discriminated human groups in terms of social, educational, and those related to the expectations of labor market insertion, making visible the link between these factors. Understanding that social exclusion takes shape according to different risk factors that interrelate with each other's character is multifactorial [83], crystallizing these forms of exclusion in certain social groups [81]. In the educational sphere, it has a priority place in the study of social integration processes, but, at the same time, we find some elements or situations that can lead to processes of educational and social exclusion or that, at least, hinder integration $[81,84]$.

\section{Methodological Aspects and Selection of Participants}

This paper seeks to respond to the questions and objectives proposed in the introduction to this article, remembering that it corresponds to a specific unit of analysis, a Colombian university institution. To this end, a qualitative methodological scheme has been designed, of an exploratory and descriptive nature [18]. The value of a qualitative approach is that, according to Castillo and Vásquez [85], credibility is achieved when the researcher collects information that produces findings that are recognized by the informants as a true approximation of what they think and feel. The perspective from which we approached the study is social and educational, placing ourselves within the framework of the hermeneutic approach, which is pertinent in that the beneficiaries of the results of this research form are, at the same time, part of its development and of the transformation of the exclusionary problems that hinder the commitment to inclusive education in the community of the university institution where the research is being carried out. The research design, as it is a first approach to the reality being addressed and as there is little literature on the subject in the context of Colombian higher education, is based on a single instrument and a single source of information or type of participants, seeking to identify significant variables in 
the subject of study. Having only one source of information is usually a characteristic of qualitative studies [86].

\title{
5.1. Instrument and Dimensions of the Study
}

A semi-structured interview was designed to help gather the main topics to be addressed based on the research questions: identification of differential groups in terms of human diversity and to learn about their social and educational trajectories, the situations of discrimination and factors of exclusion to which they have been exposed, among other topics covered. According to Hernández, Fernández and Baptista [87], it is advisable to start from the most general to the most particular, making it easier for both the interviewee and the interviewer. Participants can express their opinions, qualify their answers, and even deviate from the initial script devised by the researcher when emerging themes that need to be explored come to light. In this case, the research started from general themes such as human diversity, social inclusion, inclusive education, delving into issues of risk factors for exclusion and discrimination. Table 1 illustrates the interview script used for the research.

Table 1. Semi-structured interview script questions.

Semi-Structured Interview Script Questions

\author{
1. Human diversity. Conception of the term and its relationship within their social group \\ 2. Social and educational background \\ 3. Prejudices and discriminations of Higher Education students \\ 4. Importance of inclusive education \\ 5. Psychosocial Factors, Risk and Discrimination \\ 6. Impact on educational practice
}

\subsection{Categorization and Analysis Techniques}

The information collected was approached using content analysis techniques, under a mixed scheme of creating qualitative analysis categories: a priori categories that were constructed based on the literature review, and subcategories that emerged from the analysis process. The categories correspond to the objectives proposed of the study. The proposed model is in line with one of the basic characteristics of qualitative research, flexibility, and the possibility of integrating new categories of analysis during the research, while at the same time allowing the researcher to give meaning to the results [88]. This entire process was carried out using Nvivo12 software, where the categorization and coding of each of the categories was established, and subsequently the content analysis was carried out.

\subsection{Sample}

The selection of the students who participated in the study was intentional and voluntary, based on the people or groups who wanted to participate and whose contact was made through the student groups formally attached to the university that champion the causes of diverse collectives; there were 15 participants in total. Prior to this, we must be clear that this project seeks to get to know the human plurality of groups and communities that have historically been discriminated against; the five priority groups were defined, as described above, and the distribution of the sample being as follows: students with disabilities (three participants); students with a diverse ethnic, racial or cultural origin (three participants); students belonging to groups of affective-sexual diversity or diverse gender identity, as well as female students who fight against gender-based non-discrimination (four participants); students in a situation of socio-economic difficulty (three participants); and students who are victims of the Colombian armed conflict (two participants). The way in which we take these population profiles in terms of social inequality does not limit the exploration of how they intersect, giving rise to a diversity of identities, situations, and social positions. 
In what follows, we show the results obtained from the interviews about aspects of identity, recognition, and belonging to diverse population groups, as well as discrimination and personal and collective risk factors.

\section{Students' Definitions of Human Diversity and Feelings about Their Identity}

A coding has been created to safeguard the anonymity of the interviewees. The first part of the coding gives an account of the human diversity group to which they belong, these groups being the following: G1 (affective-sexual diversity and gender discrimination), G2 (socio-economic hardship), G3 (ethno-cultural diversity), G4 (disability status), and G5 (victims of armed conflict). The next two numbers identify the participant within the group.

Participants were asked about the concept of human diversity and how they would define it, showing an association between the concept of diversity and the population groups that are commonly subject to discrimination. Thus, diversity is interpreted mainly from the collective and relational (and not from the individual), in correspondence with characteristics or features of ethnic and cultural identity, forms of disability, gender, and religion, among others. At the same time, they recognize that the diverse nature of a group determines and influences the perceptions, beliefs, and ways of thinking and acting of all its members.

However, this affinity to a collective does not deny the participants their own individual characteristics. Belonging to a specific group does not generalize characteristics and qualities for all its members; on the contrary, it recognizes that each human being has certain differences, which is a contribution to the group. In this way, recognizing the character of differentiation and particularity attributed to this concept, in some testimonies, it is possible to identify that the participants consider that diversity is an implicit characteristic of the human being. As can be seen in the following testimony, which begins by highlighting the general (collective) to the particular (individual), valuing diversity as something natural to every human being, without ascription to any group traditionally identified within the differential approach, and how this has repercussions on the facets in which their lives develop:

G2_02: "Well, diversity is a difficult concept [ . . . ] the approach I have always heard is about sexual diversity or geared towards that gender approach. But for me the concept of diversity goes much further, diversity is implicit in the human being and in all the things that surround us. Diversity is people, each person is unique, diverse."

Several of the students' voices conceive diversity from the point of view of the significant contribution that each subject or group can make, rejecting it as a segregating criterion. The participants' definitions show that what is diverse is related to each person's ascription and identification [18] with the characteristics, interests, and ideals of the different groups. In this sense, diversity is the feeling of being different from others by belonging to, recognizing oneself, and identifying oneself with something specific that is different from other groups. From this perspective, we proceed to the analysis of the testimonies related to the category of belonging to diverse population groups. Some participants can ascribe and identify with certain diverse groups, given that within these collectives they share certain ideals, thoughts, traditions, traits, and expressions:

G2_03: "As part of Pilo Paga, I think that something that characterizes us quite a lot is our simplicity, we are not ostentatious [ ... ] So, I also consider myself humble, we are very humble and collaborators [... I I can vouch that most of the Pilos at the university are collaborators, humble and very intelligent people."

In this and other testimonies, young people show a strong sense of belonging and identification with the group, as well as the appropriation of the group's own vocabulary and stereotypes. Similarly, the differences with respect to "the others" are exalted and one's own traits are praised.

Likewise, another of the perspectives that arise in the testimonies is to identify and define themselves according to their socio-family conditions and life histories from the ori- 
gin, this being the differentiating factor that they highlight. Moreover, in some testimonies it can be interpreted that the fact of feeling belonging to certain groups is rooted in the cultural traditions and customs that are promoted from the family environment, and that in this way the participants naturalize it and assume it as part of their lives:

G3_01: "I do indeed consider myself a diverse human being, but it is thanks to cultural construction [ ... ] My parents make me a descendant of a community, in this case, Afro-Colombian, Palenquera (Native of San Basilio de Palenque).

In one testimony, however, it is visible that the family trajectory as a victim of the Colombian armed conflict, and the recognition of this situation suffered and how it impacted the development of the family nucleus, does not manifest itself in a feeling of belonging to the group of victims of the conflict.

Several of the interviewees made it clear in their responses that identity is a dynamic and modifiable process. For example, there is a case mentioned around the fact of an acquired disability in the development of the person. Also noteworthy is the feeling of one of the participants whose response testifies to how society and the way in which diversity is assumed becomes an obstacle or limit to the exploration of the self and the process of self-recognition:

G1_01: "I have been in this search to recognize who I am and try to find my place in the world, because I am from a small town and not many people there are so open [...] everyone has a very closed standard of how things should be, women are women, men are men, women act in such and such a way, men act in such and such a way [ ... ] I don't comply with certain factors that determine women and at the same time I do comply with some that determine men ... that's why I say that ... I mean ... I'm non-binary because sometimes I feel like a boy, sometimes I feel like a girl."

\section{Prejudices and Discrimination of Diverse Groups in the Trajectories of the Participating Students}

In the research we wanted to differentiate three possible situations of prejudice and discrimination, so that the students could share their perceptions or experiences. These are situations of discrimination in which the participants have been witnesses (neither victims nor perpetrators), situations of discrimination that they have suffered throughout their lives in the different environments in which they have lived, and situations of discrimination that they have experienced within the university institution.

The participants in the study, when asked the question about situations of discrimination they have experienced at university, often receive the question with a surprising attitude and even their first response is to deny such events, with a large group of participants denying categorically that they feel they have been victims of any situation of discrimination at the educational institution. The trajectory of the students at the university who feel that they have not been discriminated against tends to be assessed based on the absence of an explicit conflict that has its origin in their diverse condition. However, some aspects and experiences come to light that they did not consider as an act of discrimination but which, after the interview, end up being identified as such.

In the testimonies of the participating students, for the three situations of discrimination described above, the following subcategories emerge in the analysis, based on which we analyze and interpret the results.

In terms of who the discriminated groups are, or features of human diversity on which the discriminatory practice is based, the following results are evident:

- Discrimination based on race and ethnic-cultural aspects: more than half of the participants value that diversity based on race is one of the discriminatory practices that they perceive as more frequent in the contexts through which they have transited in their lives, being the black, Afro-Colombian, and Raizal community, those who suffer from it the most. The testimony of a student belonging to a Colombian indigenous community whom we were able to interview is valuable, who, from her own experience since she was a child, shared with us that her mother was always the object 
of discriminatory attitudes, since her expression is that of her ethnic group in terms of clothing.

- Sexism based on diverse gender identity and against affective-sexual diversity: more than half of the participants state that people with non-heterosexual sexual orientation and the LGTBI collective, as well as those who freely express a diverse gender identity, are one of the groups that suffer the most discrimination in society, according to their experiences.

- Discrimination based on socio-economic aspects: there are allusions to situations of discrimination towards people who belong to a low socio-economic stratum 4, i.e., who are in socio-economic difficulty. In this sense, there are not many direct answers that our participants give us about this group, although it is a recurrent and constant theme throughout the development of several of the interviews and one of the most pointed out when we talk about situations experienced in the university institution.

- Discrimination due to disability: situations of disability have been mentioned by two participants as a discriminatory motive, only when it is discrimination due to physical issues, when it is visually perceived, and the discriminatory practice is based on this.

- Discrimination between regions of the Colombian territory: within Colombia there are manifestations of rivalry and rejection based on regional differences. Attitudes and verbalizations on the coast against people from the interior and vice versa are alluded to, to which is added a testimony against people of insular origin (San Andrés) and another that emphasizes physical (racial) features different from those of the community where they live as the basis of this discrimination. Two of the people who have experienced this type of attitude are displaced by the armed conflict, from the interior of the country to the Colombian Caribbean coast.

- Machismo against women: there is only one mention of discrimination against women to the detriment of men when asked about situations they have witnessed, of which they have not been victims. The only participant, a member of the group fighting against discrimination against women, refers to having experienced situations of discrimination in her daily life, but not specifically in her time at the university.

All these reasons are manifested in the three categories or levels of discrimination, with the difference that when we ask about general situations that have not been direct towards them, they mostly mention that this occurs towards Afro-Colombian populations and others discriminated against based on race and sex/gender diversity, while when we ask about their own, they always mention the characteristics of the diverse group to which they belong as a reason.

Among the participants' responses, there is also a remarkable testimony that shows an attitude of denial of the experience of discriminatory situations since, even if they occur, she has the tools to deal with them. This is based on the mistaken idea that having the ability to defend oneself negates the discriminatory act:

G3_01: "Mmm ... discrimination Me? No. [ . . . I If a person starts to attack me and I know my rights, I am not going to let them, if a person ... I defend myself."

We also have information on who discriminates and the place or environment where the discrimination takes place, two subcategories that are intricately linked in each of the three types of discrimination we asked about. Educational environments, especially at the pre-university level, appear as those where discrimination most frequently takes place. School is one of the places where these people have suffered the most discrimination throughout their lives, with discriminatory practices among peers or classmates being the most frequently mentioned and with specific particularities, as they occur daily and repeatedly. Teachers and, in general, educational institutions are also mentioned, from their own structure, as discriminatory entities. The cases of discrimination that are suffered in the university context refer to those exercised in university spaces other than the institution that is the focus of this work. For example, rejection or mockery by classmates, and a humiliation by a teacher in class at a university in the Colombian Caribbean region is also described. The differences and rejection between students who belong to public and 
private university environments are exposed by a participant who is part of a scholarship program that finances her studies at a private university. She states that she is not accepted by her university peers from public institutions.

The events perceived as discriminatory within the university to which the students belong have been widely described. The staff of the different departments that provide services at the university (security, catering, commerce, and leisure services) are those who are repeatedly cited by the student participants as executing bad practices or actions of rejection against various people belonging to disadvantaged groups (mainly LGTBI, diverse gender identities, and the Afro-Colombian community). There are also testimonies of how tensions are generated between peer groups and explicitly discriminatory actions against subjects. For example, in the use of the university's common and social spaces (amphitheater, spaces for lunch and outdoor student meetings, porches), attitudes of prejudice or rejection are produced by the public who make use of the facilities and open spaces towards people with expressions of diverse identities. Additionally, in academic spaces (classrooms and other spaces for teaching and study), some of the described situations of discrimination between peers occur.

The family environment is also shown by some participants as a place where discrimination among its members takes place. In the participants' life stories, they describe how their family members have instilled in them prejudices and discriminatory attitudes against groups of human diversity. Within the family, there is also direct rejection of people of human diversity, as reported by one participant who says that he has been directly affected by his family members.

The participants also describe situations in which people from ordinary society or professionals working in public spaces (in the street, sports stadiums, bakeries, shopping centers, restaurants and cinemas) display discriminatory attitudes. These have been highlighted both in terms of perceptions and situations experienced as observers, as well as those experienced by the participants themselves. It is worth highlighting the number of participants who show situations in which these events occur in shopping centers because of socio-economic issues or rejection of the LGTBI community. Similarly, cities appear as spaces where strong resistance to the regional diversity of the country is generated. On several occasions, participants report having received comments undervaluing their place of origin in rural areas or smaller cities.

The next subcategory to be analyzed is the one that provides us with information on the type of prejudice or discrimination, as stipulated in the literature discussed above [69-75]:

- Prejudice or intolerance (attitude): when we ask about discrimination in general against diverse groups, information is collected about sexist attitudes, the consideration of different capacities based on sex or gender, intolerant attitudes towards diversity of any kind, and adherence to collective imaginaries based on stereotypes. When they talk about those of which they have been protagonists, there are cases that repeatedly refer to an attitude of indifference and invisibility in the face of a situation experienced by processes of construction of a non-normative identity, on the part of the people close to them in their environments.

- Direct discrimination: almost all the discriminations expressed in the interviews, in the three cases consulted with the participants, are examples of direct discrimination. The actions mostly described, we have grouped into the following practices: insults, humiliation, and verbal discriminatory treatment; mockery, sarcasm, and jokes (for example, mockery due to disability or different rural or regional origin); deprivation of the use of a space or service (members of the security corps interrupting events or preventing diverse groups from entering the university); rejection or segregation (when colleagues do not include people different from the common in their activities); erroneous beliefs about differential attention to groups (denial of the capacities of ethnic groups or people with disabilities). The descriptions of situations of humiliation are very explicit and direct towards the victim person or group: 
G1_02: "A physics professor [at a university in the Colombian Caribbean region different from the one in the study] discriminated against a boy because of his specific way of speaking and expressing himself. He told him that if he was going to be in his class, he had to be a man or else he was going to lose it or he would drop out or leave."

G3_01: "[the department in charge of the restaurant and commerce service at the university of the study] has some characters and there were three men dressed as women, dressed as Afro women with their skin painted black, with a turban, with skirts, that is, doing the characteristics of those Afro-descendant women who were offering empanadas and fried food but also these young people had a tone of voice, let's say, burlesque, of what is or how these Afro-descendant men and women speak."

- Indirect and/or structural discrimination: in our results, the testimonies report situations of schools that deny an education that promotes human and children's rights and do not attend to human diversity and its promotion, always in favor of some groups to the detriment of others. Another recurrent idea in the interviews is related to the regions and the idiosyncrasies and tendencies in each of them. For example, it was mentioned by several participants that the Caribbean coast, and specifically Barranquilla, is a territory in which discrimination on grounds of sexual orientation or gender identity is assumed daily. In the case of the situations that occurred during their time at the university in the study, there are several accounts that show the imaginaries or stigmas about the institution or about the programs offered in it, which generate feelings of shame and concealment of belonging to the institution due to the imaginary that exists about it. Another account speaks of situations of competition and distancing between students from different degree programs, as a form of indirect discrimination.

G4_03: "Here at this university I had a problem because I wanted to study music and the professors who auditioned me, several of them told me: hey, with that device [tracheotomy], it is very unlikely that you will have a good career as a musician."

- Multiple discrimination: some of the participants acknowledge having been victims of multiple discrimination. The cases mention situations of confluence of discriminations, such as: disability status-region of origin, socio-economic status-place of residence, and even that which is a confluence of up to three elements (socio-economic status-racial, physical-racial, and socio-economic status-racial traits-origin from a rural environment).

\section{Risk Factors of Diverse Groups to Which Students Belong}

The results about the risk factors to which the participating students are exposed as part of the groups to which they belong have been organized into different subcategories created from content analysis of their testimonies. The emphasis in the interview was to find out the risk factors for social and educational exclusion. In addition, each group highlights the situations specific to the group, although there are many common risk factors among them, as social disadvantages are sometimes shared.

The risk factors for labor market integration are causally related to the students' expectations or first contacts with work and their assessment in terms of employability. Therefore, almost all the responses focus on describing the difficulties in terms of access to employment for different groups. They see as a future risk for socio-occupational integration the assessment that employers may make of their group (especially in the case of affective-sexual diversity and gender identity), as well as being relegated to specific jobs despite qualifications. Members of ethnically and racially diverse groups, people with disabilities, and victims of conflict also mention the fear of suffering this type of rejection in job selection processes.

Educational risk factors, understood by the participants as previous situations that imply a disadvantage in terms of educational projection and continuity, are related to 
difficulties in accessing higher education due to diverse gender identity and expression, which interferes in the processes of access to higher education. In addition, the group has additional difficulties of a socio-familial, socio-health, or socio-economic nature that limit their opportunities for access and permanence, as the following testimony indicates:

G1_02: "A trans person does not go unnoticed like that. They are often thrown out of their homes, they don't have money to pay for a university, in public universities they are discriminated against [ ... ] they have to work and study."

The quality of education in training prior to accessing the higher education system is referred to on several occasions as part of the trajectory of exclusions and difficulties of low socio-economic groups, and those displaced as victims of the conflict from rural to urban areas. Differences based on origin, whether due to language or development in a rural world, are expressed by an indigenous student as a disadvantage when it comes to accessing university studies (which are in urban centers and operate with criteria far removed from indigenous idiosyncrasies), due to the differences in educational institutions in both contexts.

When access is assured, which is the case of our participants, difficulties in remaining in the educational system emerge. Financial shortcomings are the problem most frequently mentioned by students in general to remain at university. Teacher training and working with a focus on analyzing the needs and potential about diversity is mentioned as an element to be considered, since inadequate attention and teaching processes on the part of teachers about human diversity generate hostility and difficulties for students, in terms of their integration and accompaniment in educational processes. Similarly, a risk expressed is the failure to generate inclusive teaching-learning processes with the general student body of the educational institutions. In terms of factors affecting specific groups, achieving good levels of emotional stability is a factor specific to people with a diverse affectivesexual orientation. Linked to the permanence and educational development of people with disabilities. Problems related to the infrastructure and spaces of educational institutions are mentioned as a risk, due to the difficulties that derive from this in terms of accessibility and mobility.

Social and/or family risk factors play a key role in the trajectories of students, as expressed by the participants in our study. Social and cultural pressure, understood as structural discrimination, is a difficulty for some of the students interviewed to recognize themselves as part of a group or to accept the struggle of certain diverse groups, for fear of being pigeonholed within them, and can be a factor in the empowerment of the group. According to the participants, the social visibility of certain groups is made more difficult. Peer pressure would be one such practice, which is widespread in the adolescent period among peers:

G2_02: "When you are young you have a lot of peer pressure [ ... ] one of the risk factors is the kind of people you interact with on a daily basis or with whom you have influence."

It is also evident that a rejection of the positive actions created to generate opportunities for groups in socio-educational difficulties is perceived as a risk for them as beneficiaries. For example, facilitating access to studies for people with disabilities is not always viewed positively, as they consider that it leads to the stigmatization of the group. The non-recognition of the capacities and difficulties of each group is again mentioned as an example of discrimination based on gender, identity, disability, and ethnic-racial diversity.

About the family environment, they mention risk factors that affect the family system, such as family uprooting due to situations of displacement of the family nucleus, which is an extremely specific factor for people who are victims of the conflict, and the absence of support networks. On other occasions, there are factors to which they are exposed that come directly from family members, such as direct rejection and denial of support by family members for the identity traits that these people develop, which is a very frequent situation among the LGTBI collective. 
In terms of economic risk factors, socio-economic gaps are a risk factor in the educational trajectory of some groups, being the basis for discriminatory attitudes on the part of other groups and generating material difficulties for the development of university studies. For example:

G2_03: "When you enter a university and you meet people of all kinds, whether they are wealthy, not wealthy, tolerant or intolerant. If you enter university with socio-economic deprivation, you feel inferior."

About ethnic-cultural groups and victims of the conflict, risk factors related to territory are key. Territory and the origin of certain groups is referred to in the testimonies as a factor that generates educational and social exclusion. Indigenous communities living in dispersed areas of the Colombian region of La Guajira encounter difficulties in accessing education and similar levels of quality as in more densely populated urban or rural areas. For victims of the conflict, rurality has also affected their educational opportunities, producing an unequal starting point when they arrive in an urban context, uprooted, disconnected from urban logics and unable to compete on equal opportunities.

\section{Conclusions}

The main results of this work indicated that there are highly visible groups of human diversity in the spheres of young university students, such as the LGTBI collective and diverse gender identities, as well as ethnic and cultural groups (black community, Afro-Colombian, Raizal, and indigenous peoples), whose members report a high level of collective ascription and identification. Likewise, this group was more frequently perceived as a victim of prejudice and discriminatory practices. These results made it possible to establish the relationship between socially and politically empowered subjects as the most visible targets of discrimination, and whose discourse and demands have had an impact on the general population.

Other groups became blurred as a group with a collective entity. They were mainly those young victims (direct or indirect) of the Colombian conflict, who exclusively recognized violence and historical and structural discrimination. Women were rarely seen as subjects exposed to general or specific risk factors or affected by direct discrimination, thus hiding the gender disadvantages that are now widely assumed.

Discrimination was a constant in the life trajectories of the participating students, although it changed at each moment described, with indirect or structural discrimination being more frequent and the educational contexts being spaces where many of them were generated and reproduced. Labor, educational (in terms of access and permanence), social, and family risk factors were best defined and assumed with greater clarity and forcefulness.

The university institution where the research was carried out was not perceived as an environment that increases risk or generates discrimination. However, it is true that there were certain prejudices and indirect discriminations (mainly related to socio-economic difficulties) and errors in their actions that deserve to be reviewed and addressed in their development. These results should be considered for subsequent proposals for approaching and studying the student community, as well as when proposing participative strategies and the creation of actions aimed at the development of Inclusive Higher Education in the university institution.

As possible implications of the research, it should be noted that it approximates the field of study, and further research is planned to make a proposal for action to respond to these groups. This study provides information on the social reality that exists in the field of higher education, something that many instructors may be unaware of and that is why they may not know how to respond. All instructors must be aware of the educational reality that surrounds their practice, from their own work context to the characteristics of their students. This can be difficult at the higher education stage due to the large number of students in class. For this reason, instructors must make an inclusive practice that involves them in their professional work. It is proposed that they encourage learning, inclusion, and participation through the resolution of concrete problems, where the student develops in 
his or her context and interest. The role of the instructor will be to encourage, stimulate, guide, advise, and assist students about technical issues, to help them to become part of the pedagogical process as the subject of their own learning. At the same time, to carry out inclusive practices that promote non-discrimination in class. Specifically, to ensure inclusive education, university teaching staff should organize their teaching practices according to the criteria of accessibility and universal design. In this way, the needs of all students are addressed and covered from the beginning of the learning process without having to resort to individual adaptations at a later stage.

The findings of this research provided a relevant information and knowledge base for the construction of inclusive educational environments at all levels and in educational stages prior to university. It also provided us with key indicators for gaining in-depth knowledge of where situations of risk, discrimination, etc., identified by the protagonists, occur and where it is necessary to have a direct impact to combat the main barriers to the achievement of educational inclusion. The main premise of inclusion and the social model and universal accessibility was that changes must take place in the environment and in the context, taking into account the needs of the person. In this way, our work, by getting closer to students' perceptions and opinions about their experiences of diversity, provided the necessary knowledge to implement changes in favor of educational improvement and, ultimately, inclusion.

\section{Limitations of the Study and Future Lines of Research}

As possible limitations of the study, we consider that the number of students interviewed may be reduced to be able to generalize the research to more plural and universal spheres. For this reason, as future lines of research, we intend to include more students from the five priority groups, such as: students with disabilities; students belonging to groups with affective-sexual diversity or diverse gender identity, as well as female students who fight against gender-based non-discrimination; students with a diverse ethnic, racial, or cultural background; students in a situation of socio-economic difficulty; and students who are victims of the Colombian armed conflict. Nonetheless, these results help us to continue working on future proposals for approaches and strategies to promote the development of educational inclusion in higher education at university level.

Author Contributions: Conceptualization, M.d.M.G.-V., M.M.-G., G.P.P.A. and L.H.-R.; Formal analysis, M.d.M.G.-V.; Investigation, M.d.M.G.-V.; Methodology, M.d.M.G.-V., M.M.-G., G.P.P.A., L.H.-R.; Visualization, L.H.-R.; Writing—original draft, M.d.M.G.-V., M.M.-G., G.P.P.A. and L.H.-R. All authors have read and agreed to the published version of the manuscript.

Funding: This research was funded by the University of North (Colombia).

Institutional Review Board Statement: The study was conducted according to the guidelines of the Declaration of Helsinki, and approved by the Ethics Committee of University of North (Colombia) (August 2016).

Informed Consent Statement: Informed consent was obtained from all subjects involved in the study.

Data Availability Statement: Data sharing is not applicable to this article.

Conflicts of Interest: The authors declare no conflict of interest.

\section{References}

1. Gómez, Y.; García-Vita, M.M. Hacia una Educación Superior Inclusiva (Towards Inclusive Higher Education). ReiDoCrea 2017, 6, 300-319.

2. Medina-García, M.; García-Vita, M.; Higueras-Rodríguez, L. La formación del profesorado universitario en discapacidad y atención a la diversidad (The training of university lecturers in disability and attention to diversity). El EEES Como Solución a las Nuevas Necesidades Educativas, In Vives López (coord); in press.

3. OREALC/UNESCO Santiago. El derecho a una educación de calidad para todos en América Latina y el Caribe (The right to quality education for all in Latin America and the Caribbean). REICE. Rev. Iberoam. Sobre Calid. Efic. Cambio Educ. 2007, 5, 1-21. 
4. Ministerio de Educación Nacional. Lineamientos de Política de Educación Superior Inclusive (Guidelines for Inclusive Higher Education Policy); Ministerio de Educación Nacional: Bogotá, Colombia, 2013. Available online: https://www.mineducacion.gov.co/1759 /w3-article-357277.html?_noredirect=1 (accessed on 21 July 2019).

5. UNESCO. Declaración Mundial Sobre Educación Para Todos y Marco de Acción Para Satisfacer Las Necesidades Básicas de Aprendizaje (World Declaration on Education for All and Framework for Action to Meet Basic Learning Needs); UNESDOC: Bangkok, Thailand, 1990. Available online: http:/ / www.unesco.org/education/pdf/JOMTIE_S.PDF (accessed on 25 January 2021).

6. UNESCO. Marco de Acción de Dakar. Educación Para Todos: Cumplir Nuestros Compromisos Comunes (Dakar Framezork for Action. Education For All: Meeting Our Common Commitments); UNESDOC: Dakar, Senegal, 2000. Available online: https://unesdoc. unesco.org/ark:/48223/pf0000121147_spa (accessed on 25 January 2021).

7. UNESCO. Informe de Seguimiento de la Ept en El Mundo. Los Jóvenes Y Las Competencias. Trabajar Con la Educación (EFA Global Monitoring Report. Young People and Skills. Working with Education); UNESDOC: Paris, France, 2013. Available online: https: / / unesdoc.unesco.org/ark:/48223/pf0000218569_spa (accessed on 25 January 2021).

8. UNESCO. Informe de Seguimiento de la Ept en El Mundo. la Educación Para Todos 2000-2015: Logros Y Desafíos (EFA Global Monitoring Report. Education for All 2000-2015: Achievements and Challenges); UNESDOC: Paris, France, 2015. Available online: https://unesdoc.unesco.org/ark:/48223/pf0000232565_spa (accessed on 25 January 2021).

9. García, M.M. La universidad inclusiva: Un reto de nuestro sistema educativo para garantizar el derecho a la educación (The Inclusive University: A challenge for our education system to guarantee the right to education). Educ. Incl. Abriendo Puertas Futur. 2020, 121, 121-137.

10. Alcaín Martínez, E.; Medina-García, M. Hacia una educación universitaria inclusiva: Realidad y retos (Towards Inclusive University Education: Reality and Challenges). Rev. Digit. Investig. Docencia Univ. 2017, 11, 4-19. [CrossRef]

11. Porter, G.L.; Stone, J.A. Les Sis Estratègies Clau per Al Suport de la Inclusió a L’Escola I a la Clase (The Six Key Strategies to Support Inclusion at School and in the Classroom). Suports 2001, 5, 94-107.

12. Angenscheidt Bidegain, L.; Navarrete Antola, I. Actitudes de los docentes acerca de la educación inclusiva (Teachers' attitudes towards inclusive education). Cienc. Psicol. 2017, 11, 233-243. [CrossRef]

13. Higueras-Rodríguez, L.; Medina-García, M. La formación de los docentes en el uso de metodologías activas para fomentar una educación inclusiva (Training teachers in the use of active methodologies to promote inclusive education). In Reflexionando Sobre la Educación Inclusiva: Una Apuesta de Futuro; Jiménez, O., Martínez, C., Eds.; Editorial Universidad de Almeria: Almeria, Spain, 2020.

14. Ainscow, M.; Hopkins, D.; Southworth, G.; West, M. Hacia Escuelas Eficaces Para Todos: Manual Para la Formación de Equipos Docentes (Towards Effective Schools for All: A Handbook for Teacher Team Building); Narcea: Madrid, Spain, 2001.

15. Escarbajal, A.; Mirete, A.B.; Maquilon, J.; Izquierdo, T.; López, J.; Orcajada, N.; Sánchez, M. La atención a la diversidad: La educación inclusiva (Attention to diversity: Inclusive education). Rev. Electrón. Interuniv. Form. Profr. 2012, 15, 135-144.

16. Viveros, M. Equidad e Inclusión en la Educación Superior. Algunos Aportes a la Discusión Desde la Escuela de Estudios de Género de la Universidad Nacional de Colombia (Equity and Inclusion in Higher Education. Some Contributions to the Discussion from the School of Gender Studies of the National University of Colombia); Universidad Nacional de Colombia: Bogota, Colombia, 2012. Available online: http:/ / bdigital.unal.edu.co/7409/1/maraviversovigoya1.pdf (accessed on 7 July 2019).

17. Herrera, M.; Acevedo, S.; Pedraza, C.; García, D.; Casas, O.; Martínez, D.; Hernández, R.; Barreto, A. Educación Inclusiva en la Educación Superior en Colombia y en la Universidad Nacional Abierta y a Distancia-UNAD (Inclusive Education in Higher Education in Colombia and at the National Open and Distance University-UNAD). Estado del Arte; Ministerio de Educación Nacional y UNAD: Bogota, Colombia, 2014. Available online: https:/ / cetics.org/educacion-inclusiva-colombia/ (accessed on 7 July 2019).

18. Mercado, A.; Hernández, A. El proceso de construcción de la identidad colectiva (The process of building collective identity). Converg. Rev. Cienc. Soc. 2010, 53, 229-251.

19. Avanza, M.; Laferté, G. Trascender la "construcción de identidades"? Identificación, imagen social (Transcending the "construction of identities"? Identification, social image), pertenencia. Rev. Colomb. Antropol. 2017, 53, 187-212. [CrossRef]

20. García, F.; Castillo, B.; García, A.; Smith-Castro, V. Bienestar psicológico, identidad colectiva y discriminación en habitantes de barrios estigmatizados (Psychological well-being, collective identity and discrimination in stigmatised neighbourhood dwellers). Pensando Psicol. 2017, 13, 41-50. [CrossRef]

21. Bunch, G. Claves para una educación inclusiva exitosa: Una mirada desde la experiencia práctica (Keys to Successful Inclusive Education: A View from Practical Experience). Rev. Educ. Incl. 2016, 1, 77-89.

22. Kart, A.; Kart, M. Academic and Social Effects of Inclusion on Students without Disabilities: A Review of the Literature. Educ. Sci. 2021, 11, 16. [CrossRef]

23. Sánchez-Teruel, D.; Robles-Bello, M.A. Inclusión como clave de una educación para todos: Revisión teórica (Inclusion as Key to Education for All: A Theoretical Review). REOP-Rev. Esp. Orientac. Psicopedag. 2013, 24, 24-36. [CrossRef]

24. Moriña, A. Inclusive education in higher education: Challenges and opportunities. Eur. J. Spec. Needs Educ. 2017, 32, 3-17. [CrossRef]

25. Kioko, V.K.; Makoelle, T.M. Inclusion in Higher Education: Learning Experiences of Disabled Students at Winchester University. Int. Educ. Stud. 2014, 7, 106-116. [CrossRef]

26. Gale, T.; Hodge, S. Just imaginary: Delimiting social inclusion in higher education. Br. J. Sociol. Educ. 2014, 35, 688-709. [CrossRef]

27. Gidley, J.M.; Hampson, G.P.; Wheeler, L.; Bereded-Samuel, E. From access to success: An integrated approach to quality higher education informed by social inclusion theory and practice. High. Educ. Policy 2010, 23, 123-147. [CrossRef] 
28. Martins, M.; Borges, M.L.; Gonçalves, T. Attitudes towards inclusion in higher education in a Portuguese university. Int. J. Incl. Educ. 2018, 22, 527-542. [CrossRef]

29. Ruijs, N.M.; Van der Veen, I.; Peetsma, T.T. Educación inclusiva y estudiantes sin necesidades educativas especiales (Inclusive education and students without special educational needs). Investig. Educ. 2010, 52, 351-390.

30. Aysanoa, P.A.C. Hacia una educación rural inclusiva (Towards inclusive rural education). Rev. Educ. Incl. 2019, 12, $225-246$.

31. Center, Y.; James, W.; Cecily, F. Towards an index to evaluate the integration of children with disabilities into regular classes. Educ. Psychol. 1991, 11, 77-95. [CrossRef]

32. Freeman, S.; Marvin, C. Academic and social attainments of children with mental retardation in general education and special education settings. Remedial Spec. Educ. 2000, 21, 3-26. [CrossRef]

33. Lindsay, G. Educational psychology, and the effectiveness of inclusive education/mainstreaming. Br. J. Educ. Psychol. 2007, 77, 1-24. [CrossRef] [PubMed]

34. Humphrey, N.; Lendrum, A.; Barlow, A.; Wigelsworth, M.; Squires, G. Achievement for All: Improving psychosocial outcomes for students with special educational needs and disabilities. Res. Dev. Disabil. 2013, 34, 1210-1225. [CrossRef] [PubMed]

35. Dessemontet, R.S.; Bless, G.; Morin, D. Effects of inclusion on the academic achievement and adaptive behavior of children with intellectual disabilities. J. Intellect. Disabil. Res. 2012, 56, 579-587. [CrossRef] [PubMed]

36. Bandura, A.; McClelland, C. Social Learning Theory; Prentice Hall: Englewood Cliffs, NJ, USA, 1977; Volume 1.

37. Vygotsky, L. Mind in Society: The Development of Higher Psychological Processes; Harvard University Press: Cambridge, MA, USA, 1980

38. Walker, A.; Dabie, N. Academic achievement and social functioning of children with and without learning difficulties. Educ. Psychol. 2007, 27, 635-654. [CrossRef]

39. Malecki, C.; Stephen, N. Children's social behaviors as predictors of academic achievement: A longitudinal analysis. Sch. Psychol. Quart. 2002, 17, 1. [CrossRef]

40. Wentzel, K. Does being good make the grade? Social behavior and academic competence in middle school. J. Educ. Psychol. 1993, 85, 357. [CrossRef]

41. Szumski, G.; Karwowski, M. Psychosocial functioning and school achievement of children with mild intellectual disability in Polish special, integrative, and mainstream schools. J. Policy Pract. Intellect. Disabil. 2014, 11, 99-108. [CrossRef]

42. Valero, D.; Viñas, T.P. Educación Inclusiva del Alumnado Inmigrante: Lecciones desde Estados Unidos, Canadá y Australia (Inclusive Education of Immigrant Students: Lessons from the United States, Canada and Australia). Multidiscip. J. Educ. Res. 2019, 7, 316-338. [CrossRef]

43. Mora, A.T.B.; Martínez, C.A.C.; Sáenz, P.A.R.; Cely, C.P.M.; Barón, A.M.R. Experiencias y evolución de los procesos de educación inclusiva (Experiences and developments in inclusive education processes). Educ. Cienc. 2020, 24. [CrossRef]

44. Álvarez, R.D.L.Á.C.; Cázarez, C.R.C. Aspectos psicosociales en el proceso de inclusión educativa durante la infancia intermedia (Psychosocial aspects in the process of educational inclusion in middle childhood). Infanc. Imágenes 2018, 17, 9-24. [CrossRef]

45. Vélez, A.P.; López-Goñi, J.J.; González, J.B. Habilidades emocionales y profesionalización docente para la educación inclusiva en la sociedad en red (Emotional skills and teacher professionalisation for inclusive education in the networked society). Contextos Educ. Rev. Educ. 2017, 20, 201-215.

46. Woodhead, M. Construcción y reconstrucción de la identidad (Identity construction and reconstruction). In El Desarrollo de Identidad Positivas. La Diversidad y la Primera Infancia; En M. Woodhead, y J. Oates (coords.); The Open University: Milton Keynes, UK, 2008; pp. 6-7.

47. Zárate, J.F. La identidad como construcción social desde la propuesta de Charles Taylor Eidos (Identity as a social construction from Charles Taylor Eidos' perspective). Rev. Filos. Univ. Norte 2015, 23, 117-134.

48. Bronfenbrenner, U. La Ecología del Desarrollo Humano (The Ecology of Human Development); Paidós: Madrid, Spain, 1979.

49. Mercedes, L. Factores determinantes del sentido de pertenencia de los estudiantes de Arquitectura de la Pontificia Universidad Católica Madre y Maestra, Campus Santo Tomás de Aquino (Determining factors in the sense of belonging of architecture students at the Pontificia Universidad Católica Madre y Maestra, Campus Santo Tomás de Aquino). Ph.D. Thesis, Universidad de Murcia, Murcia, Spain, 2014. Available online: https: / / www.tdx.cat/bitstream/handle/10803/284952/TLMBA.pdf?sequence=1 (accessed on 20 January 2021).

50. Nápoles, D. Elaboración metodológica y de acercamiento al análisis de la identidad colectiva urbana. Caso de studio (Methodological elaboration and approach to the analysis of urban collective identity. Case study): Ocotlán, Jalisco México. Tecnogestión $2018,15,66-74$.

51. Gimeno-Sacristán, J. La construcción del discurso acerca de la diversidad y sus prácticas (The construction of the discourse on diversity and its practices). Rev. Aula Innov. Educ. 1999, 82, 67-72.

52. Pinedo, R.; Arroyo, M.J.; Berzosa, I. Género y educación: Detección de situaciones de desigualdad de género en contextos educativos (Gender and education: Detecting situations of gender inequality in educational contexts). Contextos Educ. 2018, 21, 35-51. [CrossRef]

53. Ordóñez, G. Discriminación, pobreza y vulnerabilidad: Los entresijos de la desigualdad social en México (Discrimination, Poverty and Vulnerability: The Ins and Outs of Social Inequality in Mexico). Región y Soc. 2018, 71, 1-30. 
54. Torres, J.A. El papel de las instituciones universitarias en la creacioón y desarrollo de servicios de orientacioón y apoyo para estudiantes con discapacidad (The role of university institutions in the creation and development of guidance and support services for students with disabilities). In Orientación Educativa en las Universidades; H. Salmerón y V. López, Coords.; Grupo Editorial Universitario: Madrid, Spain, 2000; pp. 125-132.

55. Cornejo-Valderrama, C. Respuesta educativa en la atención a la diversidad desde la perspectiva de profesionales de apoyo (Educational response in the attention to diversity from the perspective of support professionals). Rev. Colomb. Educ. 2017, 73, 77-96.

56. Bausela, E. Atención a la diversidad en educación superior (Attention to diversity in higher education). Profr. Rev. Curríc. Form. Profr. 2002, 6, 1-11.

57. Guido, S. Diferencia y educación: Implicaciones del reconocimiento del otro (Difference and education: Implications of the recognition of the other). Rev. Pedagog. y Saberes 2010, 32, 65-72.

58. Aguilar, M. Educación, diversidad e inclusión: La educación intercultural en perspectiva (Education, Diversity and Inclusion: Intercultural Education in Perspective). Ra Ximhai 2013, 9, 49-59.

59. Grimson, A.; Karasik, G. Estudios Sobre Diversidad Sociocultural en la Argentina Contemporánea (Studies on Sociocultural Diversity in Contemporary Argentina); CLACSO: Ciudad de Buenos Aires, Argentina, 2017. Available online: http://biblioteca.clacso.edu.ar/ clacso/se/20170922021635/Diversidad_Sociocultural.pdf (accessed on 16 January 2021).

60. Morin, E. Los Siete Saberes Principales Para la Educación del Futuro (The Seven Core Skills for the Education of the Future); UNESCO: Paris, France, 1999.

61. Escudero, J.M.; Martínez, B. Educación inclusiva y cambio escolar (Inclusive education and school change). Rev. Iberoam. Educ. 2011, 55, 85-105.

62. Ainscow, M. Desarrollo de Sistemas Educativos Inclusivos (Developing Inclusive Education Systems); The University of Manchester: San Sebastián, Spain, 2003. Available online: http:/ / sid.usal.es/idocs/F8/FDO6565/mel_ainscow.pdf (accessed on 7 July 2019).

63. Ainscow, M. Developing inclusive education systems: What are the levers for change? J. Educ. Chang. 2005, 6, 109-124. [CrossRef]

64. Montes, B. Discriminación, prejuicio, estereotipos: Conceptos fundamentales, historia de su estudio y el sexismo como nueva forma de prejuicio (Discrimination, prejudice, stereotypes: Fundamental concepts, history of their study and sexism as a new form of prejudice). Rev. Iniciac. Investig. 2008, 3, 1-16.

65. Julián, I.; Donat, A.; Bernabeu, I. Estereotipos y prejuicios de género: Factores determinantes en salud mental (Gender Stereotypes and Prejudice: Determinants of Mental Health). Rev. Norte Salud Mental 2013, 11, 20-28.

66. Ramírez, E.; Estrada, C.; Yzerbyt, V. Estudio correlacional de prejuicio y discriminación implícita y explícita en una muestra magallánica (Correlational study of implicit and explicit prejudice and discrimination in a Magellanic sample). Revista Atenea 2016, 513, 251-262.

67. Brander, P.; De Witte, L.; Ghanea, N.; Gomes, R.; Keen, E.; Nikitina, A.; Pinkeviciute, J. Compass: Manual de Educación en los Derechos Humanos con Jóvenes (Manual on Human Rights Education with Young People); Consejo de Europa: Madrid, Spain, 2015. Available online: https:/ /rm.coe.int/compass-spanish-2015/168077bbdf (accessed on 19 January 2021).

68. UNESCO. Educación 2030: Declaración de Incheon Y Marco de Acción Para la Realización Del Objetivo de Desarrollo Sostenible 4. Hacia Una Edu-Cación Inclusiva Y Equitativa de Calidad Y Un Aprendizaje a Lo Largo de la Vida Para Todos (Education 2030: Incheon Declaration and Framework for Action to Realize Sustainable Development Goal 4. Towards Inclusive and Equitable Quality Education and Lifelong Learning for All); UNESDOC: Incheon, Korea, 2015. Available online: http://unesdoc.unesco.org/images/0024/002456/245656s.pdf (accessed on 21 January 2021).

69. Resurrección, L. La discriminación y algunos de sus calificativos: Directa, indirecta, por indiferenciación, interseccional (o múltiple) y estructural (Discrimination and some of its qualifiers: Direct, indirect, indiscriminate, intersectional (or multiple) and structural). Rev. Pensam. Const. 2017, 22, 225-290.

70. Solís, P. Discriminación Estructural Y Desigualdad Social. Con Casos Ilustrativos Para Jóvenes Indígenas, Mujeres Y Personas Con Discapacidad (Structural Discrimination And Social Inequality. With Illustrative Cases For Indigenous Youth, Women And People With Disabilities); SEGOB y Consejo Nacional para Prevenir la Discriminación; CEPAL: Ciudad de México, Mexico, 2017. Available online: https:/ / www.conapred.org.mx/documentos_cedoc/Discriminacionestructural\%20accs.pdf (accessed on 19 January 2021).

71. Carrasco, S. Análisis de la realidad de las mujeres en situación o riesgo de exclusión social en la Comunidad Autónoma de Euskadi (Analysis of the reality of women in a situation or at risk of social exclusion in the Autonomous Community of Euskadi). Zerbitzuan 2017, 64, 141-151. [CrossRef]

72. Sánchez, M.; Hernández, L.; Pérez, G. Un Acercamiento a la Discriminación. De la Teoría a la Realidad en el Estado de México (An Approach to Discrimination. From Theory to Reality in the State of Mexico); Comisión de Derechos Humanos del Estado de México: Toluca, Mexico, 2013. Available online: http://www.codhem.org.mx/localuser/codhem.org/difus/libros/libro\%20discriminacion.pdf (accessed on 19 January 2021).

73. Añón, M.J. Principio antidiscriminatorio y determinación de la desventaja (Anti-discrimination principle and determination of disadvantage). Isonomía. Rev. Teoría Filos. Derecho 2013, 39, 127-157. [CrossRef]

74. Nash, C. Estudio introductorio (Introductory study). In Derechos Humanos y Mujeres: Teoría y Práctica; Lacrampette, N., Ed.; Universidad de Chile: Santiago de Chile, Chile, 2013; pp. 13-29.

75. Rey, F. La discriminación múltiple, una realidad antigua, un concepto nuevo (Multiple discrimination, an old reality, a new concept). Rev. Esp. Derecho Const. 2008, 84, 251-283. 
76. Hein, A. Factores de Riesgo y Delincuencia Juvenil, Revisión de la Literatura Nacional e Internacional (Risk Factors and Juvenile Delinquency, A Review of National and International Literature); Fundación Paz Ciudadana: Santiago de Chile, Chile, 2000. Available online: http://saludxmi.cnpss.gob.mx/inpsiquiatria/portal/saludxmi/biblioteca/sinviolencia/modulo_2/Factores_de_riesgo_ delicuencia_juvenil.pdf (accessed on 7 July 2019).

77. Tisseron, S. La Resilience (Resilience); Presse Universitaires de France: París, France, 2007.

78. Ortega, P.; Plancarte, P. Discapacidad: Factores de riesgo y prevención y profesionales relacionados (Disability: Risk factors and prevention and related professionals). Enseñ. Investig. Psicol. 2017, 22, 183-196.

79. Prevert, A.; Navarro, O.; Bogalska-Martin, E. La discriminación social desde una perspectiva psicosociológica (Social discrimination from a psycho-sociological perspective). Rev. Psicol. 2012, 4, 7-20.

80. Moreno, B.; Báez, C. Factores y Riesgos Psicosociales, Formas, Consecuencias, Medidas y Buenas Prácticas (Psychosocial Factors and Risks, Forms, Consequences, Measures and Good Practices); Ministerio de Trabajo e Inmigración y Universidad Autónoma de Madrid: Madrid, Spain, 2010. Available online: http:/ / www.insht.es/InshtWeb/Contenidos/Documentacion/PUBLICACIONES\%20 PROFESIONALES/factores\%20riesgos\%20psico.pdf (accessed on 19 January 2021).

81. Jiménez, M. Aproximación teórica de la exclusión social: Complejidad e imprecisión del término. Consecuencias para el ámbito educativo (Theoretical approach to social exclusion: Complexity and imprecision of the term. Implications for the educational field). Revista Estud. Pedagógicos 2008, 34, 173-186.

82. Subirats, J. Análisis de los Factores de Exclusión Social. Serie Documentos de Trabajo $N^{o} 4$ (Analysis of Social Exclusion Factors. Working Paper Series No. 4); Fundación BBVA: Cataluña, Spain, 2005. Available online: https://www.fbbva.es/wp-content/uploads/2017 /05/dat/DT_2005_04.pdf (accessed on 7 July 2019).

83. Tezanos, J.F. La Sociedad Dividida. Estructuras de Clase y Desigualdades en las Sociedades Tecnológicas (The Divided Society. Class Structures and Inequalities in Technological Societies); Biblioteca Nueva: Madrid, Spain, 2001.

84. Jiménez, M.; Luengo, J.; Taberner, J. Exclusión social y educativa como fracasos. Conceptos y líneas para su comprensión e investigación (Social and educational exclusion as failures. Concepts and lines for understanding and research). Profr. Rev. Curríc. Form. Profr. 2009, 13, 11-49.

85. Castillo, E.; Vásquez, M.L. El rigor metodológico en la investigación cualitativa (Methodological rigour in qualitative research). Colomb. Méd. 2003, 34, 164-167.

86. Salgado Lévano, A.C. Investigación cualitativa: Diseños, Evaluación del Rigor Metodológico y Retos (Qualitative Research: Designs, Assessing Methodological Rigour and Challenges). Liberabit 2007, 13, 71-78.

87. Hernández Sampieri, R.; Fernández, C.; Baptista, P. Metodología de la Investigación (Research Methodology), 6th ed.; McGraw-Hill: Ciudad de Mexico, Mexico, 2014.

88. Cisterna, F. Categorización y triangulación como procesos de validación del conocimiento en investigación cualitativa (Categorisation and triangulation as knowledge validation processes in qualitative research). Theoria 2005, 14, 61-71. 